\title{
Fiddling Around the Edges: Mainstream policy responses to the housing crisis since 2016
}

\section{Introduction}

Housing is a defining social policy issue of our time. Its drivers are global, deep-rooted and can differ significantly by locality. The situation in London, for example, is disproportionate to other parts of the UK. But allowing for geographic variations, some general features are clear. An acute shortage of genuinely affordable homes is linked to multiple societal issues, including poor health, impaired education, rising crime, inequality and impoverishment. It is producing significant urban demographic shifts and contributing to the breakdown of intergenerational support networks within working class communities. Women, minority ethnic groups and disabled people are more likely to suffer the consequences of what government acknowledges is a "broken" system. Inability to fix a problem afflicting millions reveals a chasm between the concerns of the elected and the electorate.

This paper largely confines itself to some of the most recent policy responses in the UK. ${ }^{1}$ It takes as its starting point the 2016 Housing and Planning Act and subsequent measures of the current Conservative government. It then considers the alternatives offered by the Labour Party, nationally and in London. Finally, it reviews the recommendations proposed by the housing charity Shelter in January 2019.

The policies discussed emerged during a period of historic political volatility. Each has differences. But it is argued that, in the final analysis, they share the weakness of operating within the same market-oriented model that has produced the crisis. As such, they are incapable of solving it.

\section{Background}

It is becoming almost superfluous to describe the severity of the housing crisis. Even the media, which historically has tended to overlook the subject, now regularly reports the latest evidence of a situation out of control. At least 320,000 people in Britain are legally defined as homeless. Many more are in temporary, insecure, unaffordable, sub-standard or unsuitable accommodation (Butler, 2018). The knock-on effects for the wider economy and society are massive. For example, according to the Office for Budget Responsibility, Housing Benefit cost $£ 21.9$ billion in 2017 -18 (OBR, 2018). In 2011, the Building Research Establishment estimated the cost to the NHS of poor housing at $£ 1.4$ billion a year (BRE, 2011). At the most tragic - and scandalous - level, 210,000 children are registered as homeless (Children's Commissioner 2019) and the Office of National Statistics estimated 597 people died in 2017 as a direct or indirect result of being homeless, an increase of $24 \%$ over the previous five years (ONS, 2018)

\footnotetext{
${ }^{1}$ Housing policies in Scotland, Wales and Northern Ireland may be subject to devolved powers and differ from those in England. However, all parts of the UK are experiencing extensive housing need.
} 
There is a tendency to see these issues as confined to London and the South-East, but they are national. $79 \%$ of households on council waiting lists are outside the capital, nearly one-third in shire districts (MHCLG 2018). Private sector rents have increased significantly all over the country since 2015 (House of Commons 2019), as has the gap between earnings and house prices (ONS 2018).

An accretion of policies has led to this. The introduction by the Conservative government led by Margaret Thatcher of the Right to Buy (1980) is often seen as the watershed moment when UK housing policy turned away from public provision towards the private market. But all subsequent administrations have continued this trend, as part of a wider re-structuring of the Welfare State. The most recent reforms should be seen in this context and against the background of the (housing induced) financial crisis of 2007 - 08, leading to the austerity programme which had a particularly significant effect on housing investment (Hodkinson and Robbins, 2013).

\section{The Housing and Planning Act}

The Housing and Planning Act (the Act) became law on $12^{\text {th }}$ May 2016. Its main elements were:

- Council tenants' rents linked to income, so called "Pay to Stay". Households with joint-income above $£ 31,000$ ( $£ 40,000$ in London) to face incremental rent increases of $15 \%$, up to full market level.

- Permanent Secure tenancies to be ended for new council tenants and replaced with time-limited agreements.

- Councils to be compelled to sell "high value" homes when they became empty. Proceeds of sales to be used for subsidies to housing association tenants to whom the Right to Buy would be extended.

- Private developers to be relieved of obligations to provide affordable rented homes on new developments, to be replaced with government-subsidised Starter Homes for first time buyers.

- Housing associations ${ }^{2}$ to be given more freedom to operate in the private market.

- Aspects of the planning system to be privatised.

Had it been fully implemented, the legislation would have fundamentally and decisively altered the UK's housing landscape. Although it continued policy themes of previous governments, the Act was a significant acceleration, particularly in relation to council housing. The underlying policy and ideological driver was to recast the sector as providing fixed-term, temporary housing, rather than the permanent homes it has provided since its creation (Broughton, 2018). This redefinition was mooted by both the $1997-2010 \mathrm{New}$ Labour government (The Telegraph, 2008) and the subsequent Conservative-Liberal

\footnotetext{
${ }^{2}$ Housing Associations are now officially - and correctly - termed Private Registered Providers, but the more familiar term is used in this paper.
} 
Democrat-led coalition (Swaine, 2010). However, it was the Act that sought to put it into practice.

The legislation attracted widespread criticism. A Guardian editorial referred to it as "ideological overreach" (The Guardian, 2016). The Local Government Association (LGA, 2016), Chartered Institute of Housing ( $\mathrm{CiH})$, Joseph Rowntree Foundation and Shelter all warned the Act would make the housing crisis worse (Public Sector Executive, 2016). This contributed to an extremely difficult parliamentary passage, with many amendments to the Bill, before it was eventually passed (The Planner, 2016). Outside Westminster, there was a furious reaction, particularly from council tenants against Pay to Stay (Roberts, 2016). A campaign organisation, "Kill the Bill" (later renamed "Axe the Act"), held a demonstration in central London on $13^{\text {th }}$ March 2016 attracting approximately 10,000 people (Bullen, 2016), probably the biggest protest against housing policy since the 1972 Housing Finance Act.

Under the weight of condemnation and resistance, almost as soon as the legislation received royal assent, it began to disintegrate. Four key elements have been dropped: Pay to Stay in November 2016 (BBC, 2016), Starter Homes in February 2017, ending of secure tenancies and sell-offs of empty council homes in August 2018 (Kentish, 2018). Extending Right to Buy to housing association tenants and changes to the planning system have been delayed. But all these policies remain law and could, theoretically, be revived.

However, some aspects of the Act have advanced, in particular the further deregulation of housing associations (HAs), which began in 1988 when government compelled them to become more reliant on private finance (Williams and Whitehead, 2015). Since the Act, some HAs have become even more detached from their identity as social landlords, with an increasing pattern of corporate mergers and involvement in market-oriented activities (Weaver, 2018).

\section{White Papers, Green Papers and Grenfell}

With its flagship housing policy holed beneath the surface, the Conservative government appeared increasingly desperate to address the housing crisis. This was magnified, in the most appalling way, by the Grenfell Tower fire on $14^{\text {th }}$ June 2017 , an incident that encapsulated the policy failures of decades (Boughton, 2018).

There was some acknowledgment of this failure in February 2017 when a white paper was published entitled "Fixing our broken housing market", but there was little in the document to suggest radical reform. LSE academics commented:

The White Paper, far from offering significant structural change, puts forward a large number of relatively minor modifications to address specific problems...(it) hardly touches issues around how to improve the existing housing market. Even within the discussion of new housing the paper says very little about affordable housing and 
provides almost no insight into major issues such as homelessness (and) the private rented sector...(LSE London, 2017)

In the aftermath of Grenfell, the government published another policy paper, "A new deal for social housing" (Ministry of Housing, Communities and Local Government, 2018). This pledges to reverse the stigmatisation seen as one of the lessons of Grenfell, but again, was criticised for its confusion, including by the $\mathrm{CiH}$ :

...the green paper falls short of setting out the kind of ambitious vision for the future of the sector that is needed. There is a lack of clarity over the role and purpose of social housing and there are mixed messages throughout the green paper on whether social housing is intended to provide long term homes that tenants can be proud of or to act as a 'spring board to ownership' for all but the most vulnerable. (CiH, 2018)

Parts of the paper did receive a cautious welcome, including by Grenfell survivors who supported a role for tenants in tightening regulation of social landlords. However, a less noticed proposal envisaged a "new programme of stock transfer", a return to the New Labour policy of privatising council homes by transferring them to HAs. The fact that HAs remain in favour with government was confirmed on $18^{\text {th }}$ September 2018 when the Prime Minister, Theresa May, announced they would receive an additional $£ 2$ billion of public funding (Walker, 2018).

Nonetheless, in a sign that policy tends not to be one directional and is subject to political pressures, in October 2018 the government announced its intention to lift the borrowing cap that has limited local authorities' ability to build new homes (Mance and Evans, 2018), conceding one of the central demands long-made by advocates of direct investment in council housing.

\section{The Labour Party Response (national)}

Since 1997, Labour's position on council housing has varied between lukewarm and hostile. But the election of Jeremy Corbyn as leader suggested the possibility of change. At the 2015 party conference, Corbyn said: “There's no answer to this crisis that doesn't start with a new council house-building programme." However, this has not been reflected in some of the party's subsequent policy positions.

In April 2018, Labour published "Housing for the Many" (Labour Party, 2018). Among 56 policy proposals were some that would represent a significant shift, including ending Affordable Rent defined as $80 \%$ of the market level and scrapping the Bedroom Tax. At the core of the strategy is a pledge to build one million "genuinely affordable homes... a majority of which will be for social rent". The ambiguity of this statement and absence of any firm commitment to council housing was noted by some housing campaigners, alongside the fact that Labour was only planning to restore housing investment to 2010 levels ( $£ 4$ billion a 
year), with some of it being directed towards arms-length Local Housing Companies (Wicks, 2018).

\section{The Labour Party Response (London)}

A portent of possible housing policy under a Labour government has been visible since May 2016 when Sadiq Khan became Mayor of London. With a budget of $£ 3.15$ billion (43\% of the national housing investment total), Khan signalled a more radical direction with statements like "My long term aim is for half of all new homes to be affordable" (Mayor of London, 2016). But as with the national Labour Party, these commitments are couched in caveats.

The key feature of Khan's policy (which the national party appears to be shadowing) is the segmentation of publically funded housing. Of the 90,000 new homes due to be built between 2016 and 2021, 35\% were to be for London Affordable Rent, claimed to be comparable to existing social rent, but with the potential to be significantly more expensive. 65\% would be split between London Shared Ownership, available to households with income up to $£ 90,000$ - significantly above the London average - and London Living Rent, described as a "rent to buy product", with time-limited tenancies, rents related to median incomes and eligibility determined by household income.

As with national party policy, initially Khan made no explicit commitment to council housing. That changed on $23^{\text {rd }}$ October 2018 with the announcement of a $£ 1$ billion programme to build 11,000 new council homes (Mayor of London, 2018). Given the relatively early stages of this policy, detailed research is limited. But there is an emerging picture that rents for these new council homes are significantly more expensive than those for existing council housing. ${ }^{3}$ This appears to be in tune with the Mayor of London's policy of stratifying housing provision, with income becoming a key determinant of who lives where. Of course, this has always been the case in general, but it represents an important divergence from one of the special characteristics of council housing - that it is not means tested. It is ironic that Sadiq Khan publically opposed the Housing and Planning Act, but is implementing "Pay to Stay" in a different form.

\section{Shelter's Vision for Social Housing}

Another intervention into the housing policy debate came in January 2019 when the housing charity Shelter unveiled a manifesto for a radical change of direction (Shelter, 2019). The document resulted from a large-scale consultation exercise, prompted by the Grenfell atrocity. It represented a significant out-bidding of the positions of the major political parties,

\footnotetext{
${ }^{3}$ Paul Burnham, from Defend Council Housing in Haringey, has analysed rents under Sadiq Khan's new council housing programme and has found, for example, that for an existing 2-bedroom council home, the weekly rent is $£ 103.02$, compared to $£ 164.24$ for new homes using the London Affordable Rent (LAR) formula.
} 
including calling for a 20 year programme to build 3.1 million "social" homes, with investment of $£ 10$ billion a year.

The report argues that building homes would pay for itself within 30 years through savings in Housing Benefit and other costs associated with current policy. However, in common with prevailing policy and political orthodoxy, Shelter use the blanket term "social housing". They fail to acknowledge the important differences between councils and housing associations, including their record as home builders (see Table 1). At the report's launch, Labour MP and former leader of the Labour Party, Ed Miliband, rightly drew attention to the country's astonishing housing achievements after 1945. But it was, emphatically, council housing, not "social housing", that carried the load. Of the 860,870 homes completed in the UK between 1949 and 1952, 82\% were built through local authorities. The proportion of new council homes reduced over subsequent years, but was still over half of total output until 1959. Throughout this period, the number of new housing association homes built a year averaged $4 \%$. Council housing continued to average over $40 \%$ of new homes built annually from 1960 - 1980, while the average percentage of new HA homes stayed in single figures. During the four decades after the war, local authorities always built at least 110,000 homes a year.

\section{TABLE 1, HOMES COMPLETED BY TENURE, UK}

(SOURCE: DCLG LIVE TABLE 241)

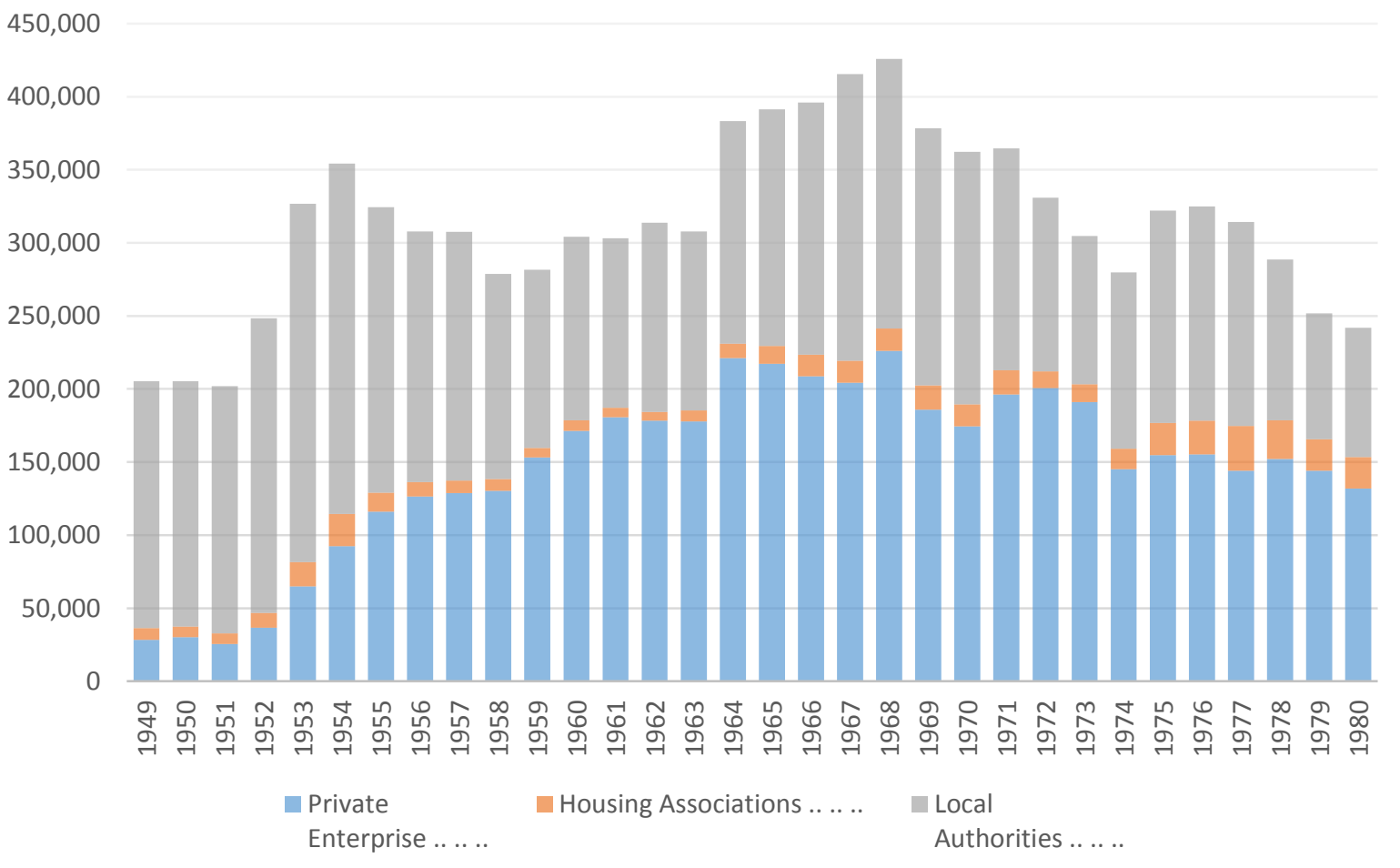


Council house building has virtually dried-up since the 1990s. Meanwhile, HAs have been promoted, by all governments, as the monopoly providers of non-market rented homes. But they have never come near filling the gap. The high-water mark of new council homes was 1953, with 245,160 homes completed. HAs have never built more than 40,000 a year, or exceeded $22 \%$ of total output. An increasing proportion of these homes have not been for social rent. In 2016, approximately one-third of the 30,000 homes completed by HAs were built by the "G15" of big London-based organisations. Of these, only $14 \%$ were for social rent. $28 \%$ were for so-called Affordable Rent of up to $80 \%$ of market level. $28 \%$ were for full market rent or market sale. The Shelter report is silent on this. There is only muted, implied criticism of the role of HAs and their creeping - in some cases, galloping commercialism. Instead, the line of the big HAs that they've been reluctant to make their corporate shift is repeated, when in fact, they actively lobbied for it (Walker, 2014).

\section{Commentary}

That a detailed report, from as credible a source as Shelter, should air-brush council housing out of history, confirms that it is still the policy that dare not speak its name. The fundamental reason for this is that publically-owned, lifetime, rented housing cuts across the ideological foundations of capitalism - private property and profit. Moreover, the restoration of council housing raises the question of control over the urban process and urban space which have largely been ceded to private development interests.

The policies described above avoid these issues. They differ in emphasis, not substance. Essentially, they advocate solutions within the existing market apparatus, but with varying degrees of intervention. In particular, each of them sees housing associations as a vehicle for mediating the worst excesses of the private development industry, without recognising that HAs are part of that industry. With every indicator showing the housing emergency deepening, a fundamental rethink is needed.

This would require challenging the hegemony of home ownership. Owner occupation reflects expressed personal aspirations (Council for Mortgage Lenders, 2016). But allowing this to dominate policy, as it has for at least four decades, fails to take account of socioeconomic trends. Home ownership in the UK fell sharply between 2007 and 2017, from 69\% to $61 \%$ (MHCLG, 2019). This shift is particularly significant amongst 25 - 34-year olds, a fall from $48 \%$ in 2007 to 34\% in 2017 (Institute for Fiscal Studies, 2018). Moreover, there is increasing awareness of the embedded inequality within the distorted housing market and its social consequences. As the Resolution Foundation points out:

In the 1980s it would have taken a typical household in their late 20s around three years to save for an average-sized deposit. It would now take 19 years. Because millennials also have less access to social housing (my emphasis) than earlier generations, almost four-in-ten of them rent privately at age $30 \ldots$ spending an average of nearly a quarter of their net income on housing, three times more than the pre-war 
generation did in their 20s. But they are getting less for their money: they are commuting longer distances than their predecessors and have less space. (Resolution Foundation, 2018)

Renting in the over-priced, under-regulated, often sub-standard private sector has now become the norm for a whole generation (House of Commons, 2018), denied the alternative of renting form the council available to those before it. However, these people have only known council housing in retreat, portrayed as last resort, not first choice. Rebuilding the sector, as part of a more balanced, sustainable and humane approach to housing will require appealing beyond the narrow scope of housing policy. An argument linking the qualities of council housing to shifting lifestyles would resonate with those currently having their lives dictated by housing. A current council tenant puts this case:

...I've been able to study, travel and write, secure in the knowledge that so long as I keep paying the rent, I'll always have a home. The importance of secure housing cannot be stressed enough... (Piggott, 2019)

A strong indication of the potential support for a revival of council housing came in summer 2019 when Channel Four aired "George Clarke's Council House Scandal”. Within two weeks of the programme, 200,000 people had signed an on-line petition backing Clarke's call for 100,000 new council homes to be built a year, for 30 years.

\section{Conclusion}

We need a new, more radical agenda for council housing that links it to the concerns of the $21^{\text {st }}$ century, rather than the rhetoric of the $20^{\text {th }}$. Public ownership, outside the volatile private market, offers the chance to address a range of social policy concerns, not just housing. Collectively owned and shared services can optimise energy efficiency and other measures to reduce domestic carbon emissions. Sub-market rents and secure tenancies can provide stability during the periods of fluctuating income now typical of the "flex-economy". The direct relationship council housing establishes with local democracy can help fill the "democratic deficit". The reestablishment of settled social networks centred on council tenants, free from the constant threat of displacement, can address a range of growing social problems, ranging from care for the elderly to the dangers facing young people. As I have written elsewhere:

Neoliberal and profit-driven urban policies have produced cities in which many young people literally feel they have no place. They find it almost impossible to find a home they can afford in the communities where they were born, thwarting their ability to develop independent lives. Their social networks, sense of belonging, and feeling of respect from the adult world have been stretched to breaking point. Nothing could be more perfectly calculated to create a situation in which young people don't care, either about the lives of others, or their own. (Robbins, 2019) 
To achieve these multiple policy benefits requires a more ambitious vision than those of recent mainstream policy responses. Fiddling around the edges isn't going to work. Like climate change, it isn't too late, but time is running out. 


\section{References}

BBC (2016) "Pay to Stay social housing plan dropped”, BBC News, 21 $1^{\text {st }}$ November 2016. Boughton J (2018) Municipal Dreams: The rise and fall of council housing, London, Verso. Boughton J (2018), Grenfell Tower and the long crisis of social housing, Red Pepper, $13^{\text {th }}$ June 2018.

Bullen J (2016) Housing Bill protest: Thousands join march to oppose 'attack on council house tenants, Evening Standard, 13 ${ }^{\text {th }}$ March 2016.

Butler P (2018) At least 320,000 homeless people in Britain, Shelter say, The Guardian, 22 ${ }^{\text {nd }}$ Nov. 2018.

Building Research Establishment (2011) The Cost of Poor Housing to the NHS, briefing paper, 2011.

Chartered Institute of Housing (2018), CiH response to a new deal for social housing, $31^{\text {st }}$ October 2018.

Children's Commissioner (2019), Bleak Houses: Tackling the crisis of family homelessness in England, August 2019.

Council for Mortgage Lenders (2016), CML research shows $80 \%$ of people aspire to own a home in ten years, $20^{\text {th }}$ October 2016.

Hodkinson S and Robbins G (2013) The Return of Class War Conservatism? Housing under the UK Coalition Government, Critical Social Policy, 33 (1), pp 57 - 77.

House of Commons (2018) Private Rented Sector, Housing, Communities and Local Government Committee, Fourth Report of Session 2017 - 2019.

House of Commons Library (2019) Private Rented Housing: The rent control debate, Briefing Paper no. 6760 Institute for Fiscal Studies (2018), The decline of homeownership among young adults, briefing note, BN224, 2018. 
Kentish B (2016) Government quietly drops plans to force council to sell off social homes, The Independent, $14^{\text {th }}$ August 2018.

Labour Party (2018), Housing for the Many: A Labour Party Green Paper, April 2018.

LSE London (2017), LSE London's response to the 'Fixing our broken housing market' consultation, $11^{\text {th }}$ May 2017.

Local Government Association (2016) Planning Bill needs changes to help councils tackle the housing crisis, The Guardian letters, $10^{\text {th }}$ April 2016.

MHCLG (2018) Households on LA waiting lists, live table 600.

MHCLG (2019) Chart 103: by tenure. Great Britain historical series.

Mance H and Evans J (2018), Theresa May lifts council borrowing cap to boost housebuilding, Financial Times, $3^{\text {rd }}$ October 2018.

Mayor of London (2016), Homes for Londoners: Affordable Homes Programme 2016 - 21

funding guidance, November 2016, p5.

Mayor of London (2018), Mayor agrees $£ 1$ billion plan to build 11,000 new council homes, 23 October 2018.

Ministry of Housing, Communities and Local Government, A New Deal for Social Housing, $14^{\text {th }}$ August 2018.

Office for Budget Responsibility (2018), Welfare spending: housing benefit, 15 May 2018.

[https://obr.uk/forecasts-in-depth/tax-by-tax-spend-by-spend/welfare-spending-housing-

benefit/]

Office of National Statistics (2018) Deaths of homeless people in England and Wales: 2013 2017, $20^{\text {th }}$ December 2018.

Office of National Statistics (2018) Housing affordability worsening in all LA areas (England and Wales). 
Piggott M (2019), People who don't live in council houses can't see the appeal. Let me explain, The Spectator, $19^{\text {th }}$ January 2019.

Porter G (2018), statement made at meeting of All Party Group of Council Housing MPs, House of Commons, $10^{\text {th }}$ October 2018.

Public Sector Executive (2016), Housing Bill could unintentionally increase homelessness LGA leaders, 11 April 2016. [http://www.publicsectorexecutive.com/Public-Sector$\underline{\text { News/housing-bill-could-unintentionally-increase-homelessness--lga-leaders] }}$ Resolution Foundation (2018), A New Generational Contract: The final report of the Intergenerational Commission, $8^{\text {th }}$ May 2018, (p55).

Robbins G (2019), quoted by Harvey D in A Tale of Three Cities, Tribune, $10^{\text {th }}$ January 2019.

Roberts Y (2016), Fear and fury of tenants who say 'pay to stay' policy punishes them for working, The Guardian, $13^{\text {th }}$ February 2016.

Shelter (2019), “A Vision for Social Housing”, Swaine J (2010), No more council houses for life, says David Cameron, The Telegraph, $4^{\text {th }}$ August 2010.

The Guardian (2016) The Guardian view on the housing bill: ideological overreach, editorial $8^{\text {th }}$ May 2016.

The Planner (2016), Housing and Planning Bill passes into law, 13 ${ }^{\text {th }}$ May 2016 [https://www.theplanner.co.uk/news/housing-and-planning-bill-passes-into-law]

The Telegraph (2008), Caroline Flint and 'Giro-land'council estates, $6^{\text {th }}$ February 2008, https://www.telegraph.co.uk/comment/3554631/Caroline-Flint-and-Giro-land-council-estates.html Walker C (2014), Freeing Housing Associations: Better financing, more homes, Policy Exchange. 
Walker P (2018), Housing associations praise May’s £2bn plans as 'total step change', The Guardian, $19^{\text {th }}$ September 2018.

Weaver M (2018), Housing association merger will lead to social cleansing, warn tenants, The Guardian, $11^{\text {th }}$ January 2018.

Wicks M (2018), We need 100,000 council homes a year, not 'affordable homes, Morning Star, $11^{\text {th }}$ June 2018.

Williams P and Whitehead C E (2015) Financing Affordable Social Housing in the UK;

building on success?, LSE Research online, October 2015.

[http://eprints.1se.ac.uk/63399/1/_1se.ac.uk_storage_LIBRARY_Secondary_libfile_shared_r epository_Content_Whitehead\%2C\%20C_Financing\%20affrodable\%20housing_Whitehead Financing\%20affordable\%20housing_2015.pdf] 